\title{
Quality Analysis of Raw Cow Milk from the Cojocna Farm, UASVM Cluj Napoca in Correlation with the Feeding Technique and Mammary Gland Health Status
}

\author{
Eugen Claudiu JURCO ${ }^{1}$, Grigore ONACIU ${ }^{1 *}$, Zamfir MARCHIS ${ }^{2}$, Laurentiu OGNEAN ${ }^{3}$ \\ ${ }^{1}$ Department of Cattle Breading, University of Agriculture Science and Veterinary Medicine Cluj- \\ Napoca, Romania \\ ${ }^{2}$ Department of Horses Breading, University of Agriculture Science and Veterinary Medicine Cluj- \\ Napoca, Romania \\ ${ }^{3}$ Department of Preclinical Education, University of Agriculture Science and Veterinary Medicine \\ Cluj-Napoca, Romania, \\ * corresponding author: gonaciu@yahoo.com
}

Bulletin UASVM Animal Science and Biotechnologies 73(2)/ 2016

Print ISSN 1843-5262; Electronic ISSN 1843-536X

DOI:10.15835/buasvmcn-asb: 12211

\begin{abstract}
Quality analysis of 576 milk samples, obtained from the eight controls was performed in 2015 at the didactics UASVM farm from Cojocna. The biological material was represented by a total of 107 cows of Romanian spotted breed. On this population, individual and overall, were analized more aspects: productive performances and the main milk quality indicators such as fat, protein, lactose, $\mathrm{pH}$, with particular reference to somatic cell counts as the main indicator of subclinical mastitis and the content of urea as the main indicator of nutritional aspects of the dairy cows. Following the official control of milk production, it was found that the milk production was on average $14.76 \mathrm{~kg} /$ day with a values of coefficient of variability between $31.05 \%$ and $40.47 \%$, depending on the controls. The chemical characteristics of 576 samples showed considerable variations from one control to another. The amount of total fat and protein was found to be on average of $3.92 \%$ and $3.37 \%$ respectively. Regarding the content of urea and somatic cells, in all tested milk samples, the lowest value were found in the fifth control, with an average of $8.04 \pm 0.6 \mathrm{mg} / \mathrm{dl}$ (for urea) and $69.20 \pm 23.3 \mathrm{cell} / \mathrm{mlx} 10^{3}$, while the highest were in the first control $19.37 \pm 0.7 \mathrm{mg} / \mathrm{dl}$ for urea, and $263.17 \pm 31.7 \mathrm{cell} / \mathrm{mlx} 10^{3}$ for the somatic cells.
\end{abstract}

Keywords: Farm, Milk, Romanian spotted breed, Quality

\section{INTRODUCTION}

Analysis of row milk samples at the farm level referring to the content of fat, protein and particularly de milk urea nitrogen and somatic cell, are useful tools for getting a general information of how well the cows are, their responding to a given rations and last but not least the mammary gland health status (Ogola et al., 2007; Ishler, 2008; Biswajit et al., 2011).

\section{AIMS AND OBJECTIVES}

The purpose of this study was to highlight the quality of raw milk, nutrition influence on milk quality and the status of mammary gland health of Romanian spotted cows bred from didactics UASVM farm.

\section{MATERIALS AND METHODS}

The biological material was represented by 107 cows of Romanian spotted breed, which have been analyzed based on 576 milksamples, obtained form the eight controls performed monthly in the period May to December 2015. All milk samples were analyzed at the Foundation for Milk Quality Control from Cluj and were considered the following parameters: milk quantity, fat, protein, 
Tab. 1. Milk composition, milk urea and somatic cell count

\begin{tabular}{ccccccccc}
\hline Traits & $\begin{array}{c}\text { No. of } \\
\text { samples }\end{array}$ & $\begin{array}{c}\text { Milk quantity } \\
(\mathrm{kg})\end{array}$ & $\begin{array}{c}\text { Fat } \\
(\mathrm{g} / 100 \mathrm{~g})\end{array}$ & $\begin{array}{c}\text { Protein } \\
(\mathrm{g} / 100 \mathrm{~g})\end{array}$ & $\begin{array}{c}\text { Lactose } \\
(\mathrm{g} / 100 \mathrm{~g})\end{array}$ & $\mathrm{pH}$ & $\begin{array}{c}\text { Urea } \\
\mathrm{mg} / \mathrm{dl}\end{array}$ & $\begin{array}{c}\text { SCC/ml } \\
\text { X 10 }\end{array}$ \\
\hline Control 1 & 107 & $15.81 \pm 0.61$ & $3.96 \pm 0.07$ & $3.44 \pm 0.04$ & $4.72 \pm 0.03$ & 6.54 & $19.37 \pm 0.74$ & $263.17 \pm 31.78$ \\
\hline Control 2 & 100 & $13.80 \pm 0.48$ & $3.81 \pm 0.06$ & $3.38 \pm 0.03$ & $4.81 \pm 0.02$ & 6.54 & $15.31 \pm 0.54$ & $249.47 \pm 30.27$ \\
\hline Control 3 & 78 & $12.21 \pm 0.49$ & $3.95 \pm 0.08$ & $3.32 \pm 0.03$ & $4.84 \pm 0.03$ & 6.55 & $14.27 \pm 0.41$ & $195.21 \pm 25.41$ \\
\hline Control 4 & 72 & $12.90 \pm 0.62$ & $3.79 \pm 0.10$ & $3.20 \pm 0.04$ & $4.75 \pm 0.03$ & 6.56 & $9.93 \pm 0.44$ & $180.81 \pm 23.67$ \\
\hline Control 5 & 43 & $15.04 \pm 0.71$ & $3.73 \pm 0.10$ & $3.47 \pm 0.07$ & $4.71 \pm 0.05$ & 6.55 & $8.04 \pm 0.68$ & $69.20 \pm 23.39$ \\
\hline Control 6 & 44 & $16.34 \pm 0.93$ & $3.63 \pm 0.11$ & $3.34 \pm 0.06$ & $4.76 \pm 0.04$ & 6.58 & $8.43 \pm 0.61$ & $119.34 \pm 34.89$ \\
\hline Control 7 & 59 & $16.60 \pm 0.69$ & $4.20 \pm 0.12$ & $3.55 \pm 0.06$ & $4.86 \pm 0.04$ & 6.51 & $14.79 \pm 0.80$ & $167.09 \pm 28.62$ \\
\hline Control 8 & 73 & $16.46 \pm 0.60$ & $4.27 \pm 0.09$ & $3.30 \pm 0.04$ & $4.70 \pm 0.02$ & 6.49 & $11.98 \pm 0.79$ & $167.67 \pm 19.95$ \\
\hline
\end{tabular}

Tab. 2. The main indicators of milk quality

\begin{tabular}{cccccccc}
\hline \multirow{2}{*}{ Traits } & \multicolumn{7}{c}{ Summary of Data } \\
\cline { 2 - 9 } & $\begin{array}{c}\text { Number of } \\
\text { Samples }\end{array}$ & Mean & $\begin{array}{c}\text { Standard } \\
\text { Deviation }\end{array}$ & $\begin{array}{c}\text { Standard } \\
\text { Error of Mean }\end{array}$ & Variability & Minimum & Maximum \\
\hline Milk quantity (kg) & 576 & 14.76 & 5.51 & 0.23 & 37.31 & 5.20 & 37.20 \\
\hline Fat (\%) & 576 & 3.92 & 0.73 & 0.03 & 18.56 & 2.44 & 6.80 \\
\hline Protein (\%) & 576 & 3.37 & 0.36 & 0.02 & 10.79 & 2.06 & 4.88 \\
\hline Lactose (\%) & 576 & 4.77 & 0.29 & 0.01 & 6.00 & 3.19 & 5.41 \\
\hline Ph & 576 & 6.54 & 0.11 & 0.00 & 1.62 & 5.18 & 6.78 \\
\hline Urea (mg/dl) & 576 & 13.75 & 6.53 & 0.28 & 47.50 & 0.20 & 45.10 \\
\hline Somatic cell (cell*10 $\left.0^{3}\right)$ & 576 & 189.50 & 222.22 & 10.50 & 117.26 & 7.00 & 986.00 \\
\hline
\end{tabular}

lactose, $\mathrm{pH}$, urea and somatic cell count (SCC). The evaluation of the main indicators of production both quantitatively and qualitatively of dairy cows milk was performed at the didactics UASVM farm.

\section{RESULTS AND DISCUSSION}

Analyzing the main indicators of milk quality produced in 2015, from the herd exploited in the UASVM farm, is found: milk production was on average $14.76 \mathrm{~kg} /$ day, the fat content was on average of $3,92 \%$, with a minimum of $2,44 \%$ and a maximum of $6,80 \%$; the protein content was on average of $3,37 \%$, with a minimum of $2,06 \%$ and a maximum of $4,88 \%$; the lactose shows an average of $4,77 \%$, and $\mathrm{pH} 6.54$.

Regarding the milk urea content, it was an average of $13.75 \mathrm{mg} / \mathrm{dl}$, with a minimum of 8.04 $\mathrm{mg} / \mathrm{dl}$ in the fifth control and maximum on the first control by $19.37 \mathrm{mg} / \mathrm{dl}$. The optimal concentration of milk urea nitrogen is between 8 and $14 \mathrm{mg} /$ dl (Ishler, 2008). If exceed $14 \mathrm{mg} / \mathrm{dl}$, it means that the protein content of forage is too high and should be reduced accordingly, and if urea level drops below $8 \mathrm{mg} / \mathrm{dl}$ means that both energy and protein forage are administered poorly.Analysing the quality of raw milk in terms of its somatic cell content, it was found that from total number of cows, $79 \%$ shows a very good udder quality, somatic cell count did not exceed $200,000 \mathrm{cell} / \mathrm{ml}$ and $21 \%$ of animals are suspected by subclinical or clinical mastitis, somatic cell counts are above $200,000 \mathrm{cell} / \mathrm{ml}$.

\section{CONCLUSION}

The research showed that the breeding of Romanian spotted breed cattle must be oriented to improve profitability by increasing animal productivity both quantitatively and especially qualitatively using rational feeding.

\section{REFERENCES}

1. Biswajit R, Brahma B, Ghosh S, Pankaj PK, Mandal G (2011). Evaluation of Milk Urea Concentration as Useful Indicator for Dairy Herd Management: A Review. Asian Journal of Animal and Veterinary Advances, 6: 1-19.

2. Ogola H, Shitandi A, Nanua J (2007). Effect of mastitis on raw milk compositional quality. J Vet Sci. 2007 Sep; 8(3):237-242.

3. Ishler $\mathrm{V}$ (2008). Interpretation of Milk Urea Nitrogen (MUN) Values. PennState Extension, DAS 2008-134. 